Victor Faria Blanc MDFRCPC, Guy Vaillancourt MD, Gilles Brisson PHD

\title{
Succinylcholine, fasciculations and myoglobinaemia
}

The prophylactic effectiveness of a small "self-tuming" dose of succinylcholine $\left(0.1 \mathrm{mg} \cdot \mathrm{kg}^{-1}\right)$, of d-tubocurarine $\left(0.05 \mathrm{mg} \cdot \mathrm{kg}^{-1}\right)$, and of pancuronium $\left(0.02 \mathrm{mg} \cdot \mathrm{kg}^{-1}\right)$ on succinylcholine-induced fasciculations and myoglobinaemia was studied in 64 healthy children (ages two to nine years), anaesthetized with halothane, nitrous oxide and oxygen. Serum myoglobin was analyzed by radioimmunoassay and taken as a tracer of muscle damage. No correlation was found between the serum levels of myoglobin and the incidence of muscle fasciculations. Self-taming with succinylcholine decreased the incidence of fasciculations $(p=0.001)$ but did not decrease the succinylcholine-induced myoglobinaemia ( $p=0.224$ ). D-tubocurarine $\left(0.05 \mathrm{mg} \cdot \mathrm{kg}^{-1}\right)$ and pancuronium $(0.02$ $\mathrm{mg} \cdot \mathrm{kg}^{-1}$ ) both significantly reduced the myoglobinaemia and the fasciculations produced by succinylcholine. The pancuronium pretreated group presented less variable values of serum myoglobin which, when compared to the control group, had a more significant $p$ value $(p<0.001)$ than for d-tubocurarine pretreated group ( $p=0.003)$.

Muscle fasciculations and increased myoglobin levels were observed in children less than four years old who received succinylcholine.

The prophylaxis of acute rhabdomyolytic renal failure due to succinylcholine (seven cases reported in the medical literature) is considered.

\section{Key words}

ANAESTHESIA: paediatric; COMPLICATIONS: muscle fasciculations, myoglobinaemia, rhabdomyolysis; PROPHYLAXIS: pretreatment, self-taming; NEUROMUSCULAR RELAXANTS: d-tubocurarine, pancuronium, succinylcholine.

From the Departments of Anaesthesia and Clinical Biochemistry, Hôpital Sainte-Justine and Université de Montréal, Montréal, Québec.

Address correspondence to: Dr. Victor Faria Blanc, Department of Anaesthesia, Hôpital Sainte-Justine, 3175 Chemin Ste-Catherine, Montréal, Québec, Canada H3T IC5.
Intravenous administration of succinylcholine produces high serum levels of creatine phosphokinase (CPK) and myoglobin (Mb), especially in children. ${ }^{1-6}$ These biochemical signs of muscle injury are enhanced by halothane ${ }^{3-6}$ and reduced by pretreatment with intravenous (IV) d-tubocurarine $(\mathrm{dTc})^{2,5-7}$ and oral dantrolene. ${ }^{7}$

Acute rhabdomyolytic renal failure due to a single IV dose of succinylcholine has been described in only seven patients. ${ }^{8-13}$ Even so, succinylcholine should be avoided in patients at risk of renal failure secondary to rhabdomyolysis: inherited muscle disorders, postural muscle compression during coma and anaesthesia, vascular occlusion, crush and electrical injury, viral and bacterial infections, hyperpyrexia, hypovolaemia, severe hypokalaemia, alcoholism and impending renal failure. ${ }^{10-13}$ If it is necessary to give succinylcholine to one of these patients (with a full stomach, for example), it is important to know whether or not myoglobinaemia can be reduced or prevented.

Ryan, Kagen and Hyman found that myoglobinaemia may coexist without gross muscle fasciculations. ${ }^{4}$ Plötz and Braun showed that an IV "self-taming" dose of succinylcholine $\langle 0.125$ $\mathrm{mg} \cdot \mathrm{kg}^{-1}$ ) fails to inhibit increases in postoperative CPK levels in children, ${ }^{14}$ although the same technique, in adults, reduced the incidence of muscle fasciculations and pain. ${ }^{15-16}$

We proposed to evaluate the ability of a small "self-taming" IV dose of succinylcholine $(0.1$ $\left.\mathrm{mg} \cdot \mathrm{kg}^{-1}\right)^{16}$ and IV pancuronium $\left(0.02 \mathrm{mg} \cdot \mathrm{kg}^{-1}\right)^{17}$ to reduce the elevations in serum $\mathrm{Mb}$ induced by halothane and succinylcholine in normal children and compare these methods of pretreatment with d-tubocurarine (dTc) $\left(0.05 \mathrm{mg} \cdot \mathrm{kg}^{-1}\right){ }^{7}$ We also examined the correlation between the frequency of muscle fasciculations and the serum levels of $\mathrm{Mb}$. 


\section{Methods}

\section{Subjects}

Sixty-four children, two to nine years old of ASA physical status I, of both sexes ( 32 males and 32 females), scheduled for correction of strabismus or tonsillectomy under general anaesthesia, were studied after informed consent was obtained from the parents. The protocol of this study was approved by the Committee on Medical Ethics of the Hôpital Sainte-Justine. Children received no drugs outside of the study.

\section{Anaesthetic technique}

Every child had the following monitoring: precordial stethoscope, continuous ECG (CM-5) with cardiotachometer, regular blood pressure measurements with an Arteriosonde 1010 (Doppler principle) and rectal thermometry. Induction was achieved with halothane (up to three per cent), nitrous oxide and oxygen ( 40 per cent) by mask. After induction (disappearance of lid reflex and tolerance of an oropharyngeal airway), anaesthesia was maintained with halothane (1.5 per cent) in nitrous oxide and oxygen ( 40 per cent), using a Bain circuit with a fresh gas flow of $260 \mathrm{ml} \cdot \mathrm{kg}^{-1}$ and manually assisted ventilation, for ten minutes, via the face mask.

A first blood sample was then drawn for the determination of serum $\mathrm{Mb}$ and $\mathrm{IV}$ atropine $\left(0.01 \mathrm{mg} \cdot \mathrm{kg}^{-1}\right)$ was then given. When tachycardia was established, an equal number of boys and girls was randomly assigned to one of four groups. In Group I $(S)$, control group $(\mathrm{N}=16)$, an IV injection of succinylcholine $\left(1 \mathrm{mg} \cdot \mathrm{kg}^{-1}\right)$, over a period of 15 seconds, was used to facilitate tracheal intubation. In Group $I I(S+S)(\mathrm{N}=16)$, after atropine, a "self-taming" dose of succinylcholine $\left(0.1 \mathrm{mg} \cdot \mathrm{kg}^{-1}\right)$ was slowly injected (over $45 \mathrm{sec}$ onds); sixty seconds later, a second dose of succinylcholine $\left(0.9 \mathrm{mg} \cdot \mathrm{kg}^{-1}\right)$ was injected, over a period of 30 seconds, to facilitate tracheal intubation. In Group $I I I(D+S)(\mathrm{N}=16)$, d-tubocurarine $\left(0.05 \mathrm{mg} \cdot \mathrm{kg}^{-1}\right)$ was injected intravenously three minutes prior to the intubating dose of succinylcholine ( $1 \mathrm{mg} \cdot \mathrm{kg}^{-1}$, over a period of 15 seconds). In Group $N(P+S)(\mathrm{N}=16)$, pancuronium $\left(0.02 \mathrm{mg} \cdot \mathrm{kg}^{-1}\right)$, instead of $\mathrm{dTc}$, was injected intravenously three minutes prior to the intubating dose of succinylcholine $\left(1 \mathrm{mg} \cdot \mathrm{kg}^{-1}\right.$, over a period of 15 seconds).

In each patient, one of the authors estimated whether muscle fasciculations were present on a "yes" or "no" basis; another author evaluated the intubation condition as adequate (easy laryngoscopy, complete paralysis of the vocal cords, no cough and no bucking) or inadequate (difficult laryngoscopy, or incomplete paralysis of the vocal cords, or cough, or bucking). Both observers were aware of the muscle relaxants used.

In each patient, before starting surgery, a second venous blood sample was drawn, for the determination of serum $\mathrm{Mb}$, ten minutes after the intubating dose of succinylcholine. The $\mathrm{Mb}$ increase was determined by calculating the difference between the second and the first serum venous values of $\mathrm{Mb}$, in each patient. Blood tubes were identified with code numbers.

\section{Biochemical analysis}

Myoglobin was determined in non-haemolysed sera using a double antibody radioimmunoassay procedure. Material used for the assay of $\mathrm{Mb}$ was supplied by NMS (Nuclear Medical Systems Inc. Cat. no. NMS 1025). This method is an adaptation of the method of Stone et al.$^{22}$ The sensitivity of the method permitted detection of $0.50 \mathrm{ng} \cdot 100 \mathrm{\mu l}^{-1}$ and the antiserum used was highly specific for myoglobin with a less than 0.1 per cent cross-reactivity with haemoglobin $\mathrm{A}$, creatine kinase-MM, $-\mathrm{BB}$, $-M B$, lactic dehydrogenase, glucose-6-phosphate dehydrogenase and cytochrome $C$. All the specimens were frozen at $-60^{\circ} \mathrm{C}$ until assayed. Paired specimens were run in duplicate on the day of the assay. The results of duplicate analysis showed a coefficient of variation of less than five per cent. High levels of myoglobin found in certain specimens of serum were reassayed, according to the protocol described, using the zero base diluent serum provided in the kit.

Statistical analysis of the results was carried out using an analysis of variance; if this showed a significant "group" effect, comparative analysis of data was made using either the Student's t test (age; sex; weight; Mb) or the Chi-square test with Yate's correction (sex; fasciculations). $\mathrm{P}<0.05$ was considered statistically significant. 
TABLE Summary of results

\begin{tabular}{|c|c|c|c|c|c|c|}
\hline \multirow{3}{*}{$\frac{\text { Group }}{\mathrm{S}}$} & \multicolumn{2}{|c|}{ Myoglabin mean $\pm S E M\left(n g \cdot m l^{-1}\right)$} & \multirow{2}{*}{$\begin{array}{l}\text { Muscle } \\
\text { fasciculations } \\
\text { present }\end{array}$} & \multirow[b]{2}{*}{$N$} & \multirow{2}{*}{\multicolumn{2}{|c|}{$\begin{array}{l}\text { Statistical comparison } \\
\text { with group } S(P \text { value })\end{array}$}} \\
\hline & \multirow{2}{*}{$\frac{\text { Control }}{20.66 \pm 1.87}$} & \multirow{2}{*}{$\frac{\text { Increases* }}{629.86 \pm 131.0}$} & & & & \\
\hline & & & 14 & 16 & $\mathrm{Mb}$ & Fasciculations \\
\hline$S+S$ & $25.60 \pm 3.62$ & $392.42 \pm 140.6$ & 4 & 16 & 0.224 & 0.001 \\
\hline$D+S$ & $21.41 \pm 2.72$ & $152.63 \pm 65.7$ & 2 & 16 & 0.003 & $<0.001$ \\
\hline$P+S$ & $22.73 \pm 1.13$ & $56.43 \pm 19.0$ & 2 & 16 & $<0.001$ & $<0.001$ \\
\hline
\end{tabular}

Control $=$ serum myoglobin $\left(\mathrm{ng}^{\circ} \cdot \mathrm{ml}^{-1}\right)$ in the first blood sample.

*Difference between the second and first serum myoglobin $\left(\mathrm{ng} \cdot \mathrm{ml}^{-1}\right)$.

\section{Results}

The four groups were comparable with respect to age, sex and weight. The intravenous dose of succinylcholine $\left(1 \mathrm{mg} \cdot \mathrm{kg}^{-1}\right)$ was always enough to produce adequate intubation condition.

Analysis of variance showed a significant difference ( $p<0.001$ ) in Mb increases.

In all groups, the control serum myoglobin (ten minutes after the start of halothane and nitrous oxide anaesthesia, but before any intravenous injection) was normal (Table).

$\mathrm{Mb}$ increases and frequency of muscle fasciculations (after the intubating dose of succinylcholine) are summarized in the Table. Self-taming with succinylcholine $\left(0.1 \mathrm{mg} \cdot \mathrm{kg}^{-1}\right)$ produced a significant inhibitory effect on muscle fasciculations but no protection against $\mathrm{Mb}$ increases. Pretreatment with d-tubocurarine $\left(0.05 \mathrm{mg} \cdot \mathrm{kg}^{-1}\right)$ and with pancuronium $\left(0.02 \mathrm{mg} \cdot \mathrm{kg}^{-1}\right)$ produced a significant inhibitory effect on the succinylcholine-induced elevations of serum $\mathrm{Mb}$ and on the incidence of muscle fasciculations. A direct statistical comparison between these two groups (D $+S$ and $P+S$ ) did not reveal a significant difference for $M b$ increases. However, the pancuronium pretreated group presented less variable results for $\mathrm{Mb}$ (Figure 1), with a more significant $\mathrm{p}$ value $(\mathrm{p}<0.001)$, when compared to the control group, than did the d-tubocurarine pretreated group $(p=0.003)$. Moreover, the pancuronium pretreated group ( $\mathrm{P}+$ S) presented a significant difference $(p=0.02)$, while the d-tubocurarine pretreated group $(D+S)$ presented a non-significant difference $(p=0.129)$, when compared to the "self-taming" group $(S+S)$ (Figure 2).

No correlation was found between the inhibitory effects on succinylcholine-induced elevations of

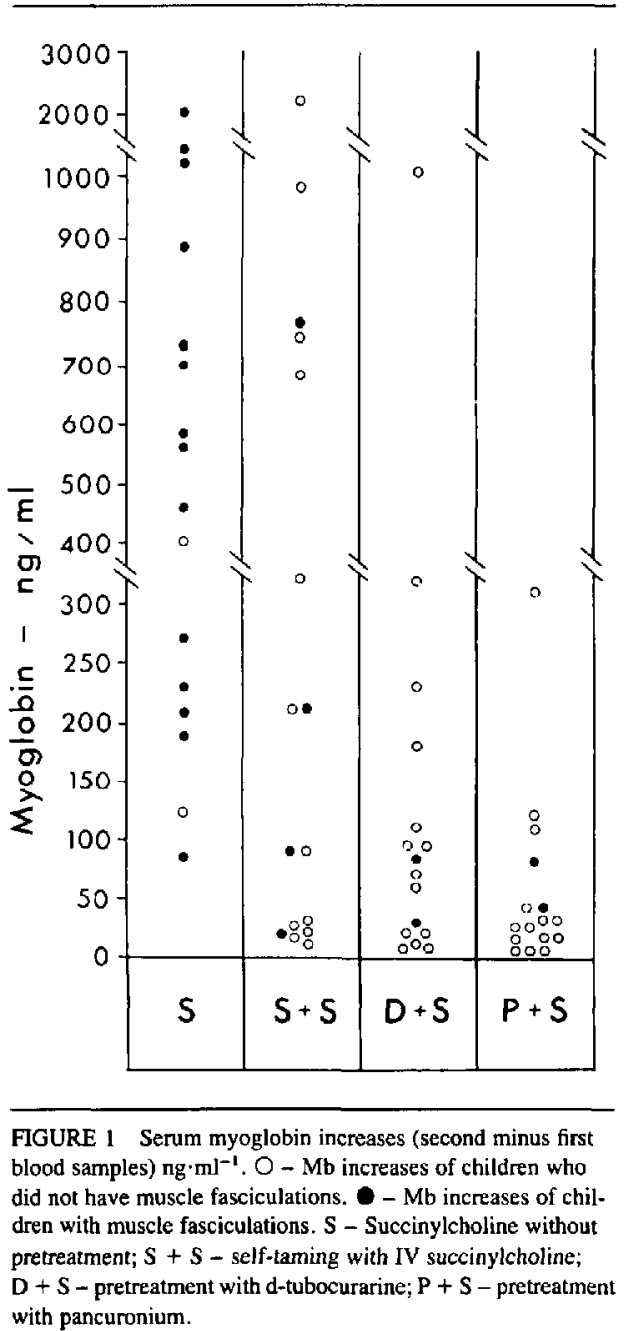




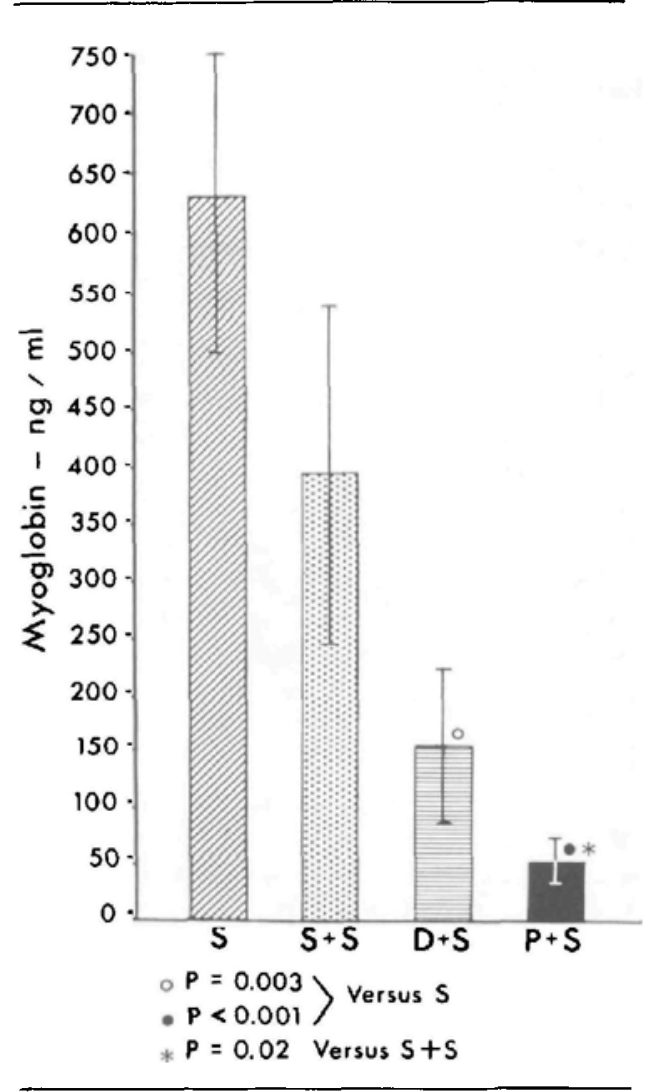

FIGURE 2 Mean ( \pm S.E.M.) increases in serum myoglobin ten minutes after the intravenous administration of succinylcholine.

serum $\mathrm{Mb}$ and the protective effects against muscle fasciculations. In fact, in each of the comparative groups $(S+S, D+S, P+S)$ the highest $M b$ increases were found in patients who had no observable muscle fasciculations. On the other hand, we observed mild elevations of serum $\mathrm{Mb}$ in seven children who did have fasciculations (Figure $1)$.

There was no predominance of myoglobinaemia in either sex. Furthermore, no significant difference was found when the $\mathrm{Mb}$ increases of younger children (two to three years old) were compared with that of the older children (seven to nine years old).

When children less than four years old were considered separately, nine of 22 (41 per cent) had muscle fasciculations; two of these patients (both three years old) developed fasciculations despite the fact that they were pretreated with either $d$ tubocurarine or pancuronium.

Pretreatment with d-tubocurarine $\left(0.05 \mathrm{mg} \cdot \mathrm{kg}^{-1}\right)$ and with pancuronium $\left(0.02 \mathrm{mg} \cdot \mathrm{kg}^{-1}\right)$ did not constitute an absolute protection against the succinylcholine-induced myoglobinaemia (Figure 1).

\section{Discussion}

Succinylcholine remains a popular and controversial muscle relaxant in modern anaesthesia. ${ }^{18}$ Its main advantage, when compared to nondepolarizing neuromuscular blockers, is the production of profound relaxation with very rapid onset and short duration of action. ${ }^{19}$

There is no doubt that IV succinylcholine ( $1 \mathrm{mg} \cdot \mathrm{kg}^{-1}$ ) produces high blood levels of $\mathrm{Mb},{ }^{4,6,7}$ with myoglobinuria, ${ }^{1}$ and high serum levels of CPK. ${ }^{2,5}$ High myoglobinaemia and elevation of CPK activity are indicators of muscle injury and serum levels of $\mathrm{Mb}$ seem to correlate with the degree of muscle damage.

This muscle injury is relatively well tolerated by healthy children and adults, but acute rhabdomyolytic renal failure must be anticipated and prevented in patients at risk. ${ }^{8-13}$

It was previously thought that a correlation existed between the intensity of muscle fasciculations and the degree of muscle damage as revealed by the serum levels of CPK and/or Mb. ${ }^{2,4.5}$ Our study does corroborate the earlier findings of Ryan, Kagen and Hyman (1971) ${ }^{4}$ : very high levels of serum $\mathrm{Mb}$ may coexist without fasciculations. Furthermore, we observed only mild increases of serum $\mathrm{Mb}$ in children who developed muscle fasciculations.

Muscle fasciculations, as well as muscle pain, can be attenuated (self-taming) by prior IV injection of a small dose of succinylcholine (0.1$0.125 \mathrm{mg} \cdot \mathrm{kg}^{-1}$ ) one minute before the subsequent intubating dose $\left(1 \mathrm{mg} \cdot \mathrm{kg}^{-1}\right) .^{15,16}$ However, the validity of the self-taming technique has been questioned. ${ }^{21}$ Plötz and Braun ${ }^{14}$ reported that in children 7-11 years old self-taming reduced the frequency of muscle fasciculations but increased, instead of inhibiting, the serum CPK activity. Our 
study, comprising children two to nine years old, confirms that self-taming significantly reduces the incidence of fasciculations ( $p=0.001$ ) but causes no significant inhibitory effect in the myoglobin increases produced by succinylcholine $(p=0.224)$ (Table, Figure 2).

These divergent effects of succinylcholine on $\mathrm{CPK}, \mathrm{Mb}$ and fasciculations disagree with the opinion that fasciculations could produce sarcolemmal breaks and permit the leaking out of macromolecules such as CPK and Mb. Hegab et al. could not find membrane breaks either in normal or in chronically denervated rat skeletal muscle following a succinylcholine challenge ${ }^{23}$ They speculate that most probably the escape of macromolecules occurs when the natural sarcolemmal channels or pores widen under the effects of succinylcholine. In any case, events in connection with the neuromuscular effects of succinylcholine other than fasciculations produce the cell damage which is responsible for the outflow of CPK and $\mathrm{Mb}$.

It is generally accepted that clinically obvious fasciculations following succinylcholine are not seen in children less than four years old. ${ }^{24,25}$ This belief is clearly incorrect. Fasciculations after IV succinylcholine can be observed in some children less than two years old. Forty one per cent of the children less than four years old included in our study had muscle fasciculations after succinylcholine administration. Two of these patients had fasciculations despite the fact that they were pretreated with d-tubocurarine or with pancuronjum. The absence of fasciculations does not mean the absence of serum $\mathrm{Mb}$ increases. In rare circumstances, succinylcholine-induced rhabdomyolysis may be complicated by renal failure.

D-tubocurarine $\left(0.05 \mathrm{mg} \cdot \mathrm{kg}^{-1}\right)$ had a significant inhibitory effect on the myoglobinaemia produced by succinylcholine (Table and Figure 2). Our results in the $\mathrm{D}+\mathrm{S}$ Group confirm the results reported by Tammisto, Leikkonen and Airaksinen (dtubocurarine reduces the elevation of serum CPK induced by succinylcholine) ${ }^{3}$ and by Asari et al. (d-tubocurarine reduces the succinylcholineinduced myoglobinaemia). ${ }^{7}$ However, we must emphasize that d-tubocurarine failed to prevent a very high increase of serum $\mathrm{Mb}\left(1080 \mathrm{ng} \cdot \mathrm{ml}^{-1}\right)$ in a seven-year-old girl who did not have fasciculations.

Pancuronium $\left(0.02 \mathrm{mg} \cdot \mathrm{kg}^{-1}\right)$ had less variable results (Figure 1) and can be seen to produce more consistent protection against succinylcholineinduced myoglobinaemia than d-tubocurarine (Figures 1 and 2).

It is possible that the differences we noted between d-tubocurarine and pancuronium may be due to our use of non-equipotent doses. Whether or not a dose of $0.1-0.15 \mathrm{mg} \cdot \mathrm{kg}^{-1}$ of d-tubocurarine has the same inhibitory effect as $0.02 \mathrm{mg} \cdot \mathrm{kg}^{-1}$ of pancuronium requires further investigation.

Halothane alone did not produce elevation of serum myoglobin, after ten minutes of anaesthesia. Intravenous succinylcholine should be avoided in patients at risk of acute renal failure. If there is an overwhelming reason to use succinylcholine in such patients, pretreatment with pancuronium $\left(0.02 \mathrm{mg} \cdot \mathrm{kg}^{-1}\right)$ appears preferred to d-tubocurarine $\left(0.05 \mathrm{mg} \cdot \mathrm{kg}^{-1}\right)$. Serum myoglobin should be measured to estimate the presence and extent of rhabdomyolysis and establish the need for treatment (correction of hypovolaemia; osmotic diuretic).

It is important to realize that the prevention of succinylcholine-induced muscle fasciculations does not mean prevention of muscle damage as revealed by myoglobinaemia. "Self-taming" with succinylcholine can produce a significant inhibitory effect on muscle fasciculations without protection against serum myoglobin increases.

\section{References}

1 Tammisto $T$, Airaksinen $M$. Suxamethoniuminduced myoglobinuria. Br J Anaesth 1965; 37: 464.

2 Tammisto $T$, Airaksinen $M$. Increase of creatine kinase activity in serum as a sign of muscle injury by intermittently administered suxamethonium during halothane anaesthesia. $\mathrm{Br} J$ Anaesth 1966; 38: 510-5.

3 Tammisto T, Leikkonen $P$, Airaksinen $M$. The inhibitory effect of d-tubocurarine on the increase of serum creatine kinase activity produced by intermittent suxamethonium administration during halothane. Acta Anaesthesiol Scand 1967; 11: 33340

4 Ryan $J F$, Kagen $L$, Hyman AI. Myoglobinaemia after a single dose of succinylcholine. $N$ Engl J Med 1971; 285: 824-7.

5 Charak DS, Dhar $C L$. Suxamethonium-induced 
change in serum creatine phosphokinase. Br $\mathbf{J}$ Anaesth $1981 ; 53 ; 955-7$.

6 Inagaki $M$, Kohyama A, Sakata S, Tonogai $R$, Yamada $Y$. Serum myoglobin levels following administration of succinylcholine during nitrous oxideoxygen-halothane anesthesia. Jpn J Anesth 1981; 29: 1476-82.

7 Asari $H$, Inoue $K$, Maruta $H$, Hirose $Y$. The inhibitory effect of intravenous d-tubocurarine and oral dantrolene on halothane-succinylcholine-induced myoglobinaemia in children. Anesthesiology 1984; 61: 332-3.

8 Bennike K-A, Jarnum S. Myoglobinuria with acute renal failure possibly induced by suxamethonium. Br J Anaesth 1964; 36: 730-6.

9 Mezzano A. Insufiencia renal aguda por rabdomiolisis aguda post-anestesica atribuible a succinilcolina. Rev Med Chile 1979; 107: 1022-5.

10 Durocher A, Chopin C, Gosselin B, Wattel F. Rhabdomyolyses toxiques et médicamenteuses. Rev Med Int 1980; 1: 223-6.

11 McKishnie JD, Muir JM, Girvan DP. Anaesthesia induced rhabdomyolysis - a case report. Can Anaesth Soc J 1983; 30: 295-8.

12 Pellici PM, Paget S, Tsairis P. Post-anesthetic myoglobinuria with acute renal failure (normothermic malignant hyperthermia). J Bone Joint Surg Am 1983; 65: 413-4.

13 Hool GJ, Lawrence PJ, Sivaneswaran N. Acute rhabdomyolytic renal failure due to suxamethonium. Anaesth Intensive Care 1984; 12: 360-4.

14 Plötz J, Braun J. Failure of "self-taming" doses of succinylcholine to inhibit increases in ostoperative serum creatine kinase activity in children. Anesthesiology 1982; 56: 207-9.

15 Baraka A. Self-taming of succinylcholine-induced fasciculations. Anesthesiology $1977 ; 46: 292-3$.

16 Strøm J, Jansen $E C$. Pain-reducing effect of sclftaming suxamethonium. Acta Anaesthesiol Scand 1984; 28: 40-3.

17 Bennett EJ, Montgomery SJ, Dalal FY, Prthvi RajP. Pancuronium and the fasciculations of succinylcholine. Anesth Analg 1973; 52: 892-6.

18 Lee C. Succinylcholine: its past, present and future. Seminars in Anesth 1984; 3: 293-302.

19 Donati $F$, Bevan DR. Suxamethonium - current status. Clinics in Anesthesiology 1985; 3: 37185.

20 Horrow JC, Lambert $D H$. The search for an opti- mal interval between pretreatment dose of $\mathrm{d}$ tubocurarine and succinylcholine. Can Anaesth Soc J 1984; 31: 528-33.

21 Mitchell LA, Brooks $J L$. Succinylcholine pretreatment unsatisfactory. Anesthesiology 1978; 48 : 297.

22 Stone MJ, Willerson JT, Gomez-Sanchez CE, Waterman $M R$. Radioimmunoassay of myoglobin in human serum - results in patients with acute myocardial infarction. J Clin Invest 1975; 56 : 1334-9.

23 Hegab E-S, Schiff HI, Smith DJ, TurndorfH. Electron microscopic study of normal and chronically denervated rat skeletal muscle following succinylcholine challenge. Anesth Analg 1974; 53: 6506.

24 Salem $M R$, Wong $A Y, \operatorname{Lin} Y H$. The effect of suxamethonium on the intragastric pressure in infants and children. Br J Anaesth 1972; 44: 166.

25 Goudsouzian NH. Muscle relaxants in children. Can Anaesth Soc J 1985; 32: S27-S31. 


\section{Résumé}

Les auteurs ont étudié la valeur prophylactique d'une petite dose de succinylcholine $\mathrm{IV}\left(0.1 \mathrm{mg} \cdot \mathrm{kg}^{-1}\right)$, de la d-iubocurarine $\left(0.05 \mathrm{mg} \cdot \mathrm{kg}^{-1}\right)$ et du pancuronium $\left(0.02 \mathrm{mg} \cdot \mathrm{kg}^{-1}\right)$, contre les fasciculations musculaires et contre l' hypermyoglobinémie narmalement déclenchées par la succinylcholime $I V$, particulièrement chez les enfants. Cette étude porte sur 64 enfants (de deux à neuf ans; état physique I de la classification ASA), anesthésiês al l'aide de l' halothane, protaxyde d'azote et oxygène. $L a$ myoglobine sérique, mesurée par radio-immunoessai, a été choisie en tant que valeur indicatrice de lésion musculaire. Aucune correlation n'a été trouvée entre l'incidence de fasciculations musculaires et les niveaux sériques de myoglobine. Le prétraitement avec de la succinylcholine $\left(0.1 \mathrm{mg} \cdot \mathrm{kg}^{-1}\right) \mathrm{IV}$ a dimunué l'incidence de fasciculations musculaires $(p=0.001)$ sans, toutefois, offrir aucune protection contre l'hypermyoglobinémie induite par la succinylcholine $(p=0.224)$. Les prétraitements avec de la d-fubocurarine $\left(0.05 \mathrm{mg} \cdot \mathrm{kg}^{-1}\right)$ et avec du pancuronium $\left(0.02 \mathrm{mg} \cdot \mathrm{kg}^{-1}\right)$, par voie intraveineuse, ont apporté des diminutions statistiquement significatives de l'hypermyoglobinémie induite par la succinylcholine IV. La comparaison directe entre ces deux groupes (d-tubocurarine versus pancuronium) ne s'est pas révélée significative. Cependant, il faut noter que le groupe prétraité avec du pancuronium a présenté des valeurs de myoglobine sérique moins discordants et une valeur de $p$ plus significative $(p<0.001)$ que le groupe prétraité avec de la d-tubocurarine $(p=0.003)$, lorsque chaque groupe a été comparé avec le groupe servant de contrôle (succinylcholine $I V$ sans aucun prétraitement).

Des fasciculations musculaires et des élévations de la myoglobine sérique ont été observées chez des enfants de moins de quatre ans.

La prophylaxie de l'insuffisance rênale aiguë par rhabdomyolyse due à la succinylcholine intraveineuse (plutôt rare: sept cas rapportés dans la littérature médicale) est envisagée. 